\section{Archaeomagnetism of four pottery kilns in central Portugal: Implications for secular variation and dating}

\author{
Michael Edwin Evans, 1 \\ Antonio Correia ${ }^{2}$
}

1 Physics Department, Institute for Geophysical Research, University of Alberta, Edmonton, Canada; ${ }^{2}$ Physics Department, Institute of Earth Sciences, University of Évora, Évora, Portugal

\begin{abstract}
We report archaeomagnetic results from four pottery kilns in Portugal which are thought to belong to the period of Roman rule ( $3^{\text {rd }}$ Century BCE-4th Century CE). Very few details have been published to date, so this broad assignment is based on the general archaeological context at each site. Our motivation was to see if a more precise chronology could be established by means of archaeomagnetic dating. Concomitant goals were to compare these results from Portugal to their counterparts in Spain and to expand geographic coverage of the regional geomagnetic secular variation reference curve. Experimentally, all the samples behaved in a very coherent manner during progressive alternating-field demagnetization and yielded high-precision mean archaeomagnetic directions $\left(\mathrm{a}_{95}<3^{\circ}\right)$ for each site. The results suggest that two of the kilns, Castelo de Vide and Peniche, were most likely in use during the late 1st/early $2^{\text {nd }}$ centuries CE, whereas the two kilns at Seixal are somewhat younger, dating to the late $2^{\text {nd }}$ to early $4^{\text {th }}$ centuries CE.
\end{abstract}

\section{Introduction}

The fact that magnetic north varies as a function of time was recognized as long ago as the $17^{\text {th }}$ century. This so-called secular variation is rather slow, involving time spans of centuries to millennia. This prompted early efforts to obtain pre-observatory records in the form of permanent magnetization carried by fired archaeological features. This undertaking has been pursued for well over a century, dating back at least as far as Giuseppe Folgheraiter's early studies in Italy (Folgheraiter, 1899). Sustained investigations, however, did not really get underway until the seminal work of Émile Thellier in France (Thellier, 1936), and its somewhat later counterpart in
Britain (Cook and Belshé, 1958; Aitken and Weaver, 1962). Since then, a substantial body of data has been built up from several European countries including Austria (Schnepp and Lanos, 2006), Belgium (Hus and Geeraerts, 1998; Spassov et al., 2008), Britain (Zananiri et al., 2007), Bulgaria (Kovacheva et al., 2014), Denmark (Abrahamsen, 1996), France (Thellier, 1981; Bucur, 1994), Germany (Schnepp and Lanos, 2005), Greece (Evans, 2006; De Marco et al., 2014), Hungary (Márton, 2003), and Italy (Evans and Hoye, 2005; Tema et al., 2006). For Spain, a few preliminary data appeared sporadically, but the first systematic compilation was published by Gómez-Paccard et al. (2006a). The only published archaeomagnetic directional data for Portugal were obtained from a vitrified wall at a Late Bronze Age settlement (Catanzariti et al., 2008). Here, we report new archaeodirectional results from four well-preserved Roman pottery kilns in central Portugal.

\section{Materials and Methods}

The kilns studied are located near the town of Castelo de Vide (kiln CD, $39.48^{\circ} \mathrm{N}$, $7.40^{\circ} \mathrm{W}$ ), at Peniche (kiln $\mathrm{PN}, 39.38^{\circ} \mathrm{N}$, $9.36^{\circ} \mathrm{W}$ ), and at Seixal (kilns QR and QS, $38.63^{\circ} \mathrm{N}, 9.10^{\circ} \mathrm{W}$ ). Kiln CD (Figure 1) is a large rectangular $(3 \times 4 \mathrm{~m})$ structure resting firmly on solid bedrock. It is in an excellent state of preservation up to the level of the firing chamber floor. Much of this perforated floor is intact, as are its supporting arches. Where it is missing, the basal parts of several arches remain in place. Kiln PN (Figure 2) is of circular construction with a diameter of $3.25 \mathrm{~m}$. Three-quarters of the perforated floor, and about $1 \mathrm{~m}$ of the firing chamber wall, remain. The underlying combustion chamber has five sturdy arches reaching a height of two metres. Peniche has been an important harbour since ancient times, and this kiln was used for the production of amphorae (Dressel 7-11 and 14, Haltern 70) destined for use in the local fishing industry. Some amphora fragments bear identifiable stamps attributed to the $1^{\text {st }}$ Century CE (Cardoso et al., 1998). Kilns QR (Figure 3) and QS are somewhat smaller than kilns $\mathrm{CD}$ and $\mathrm{PN}$, measuring approximately $2 \times 3 \mathrm{~m}$. Nothing remains of the firing chambers, but the combustion chambers and their access corridors are well preserved. Due to time constraints, solar bearings were not determined for samples from kiln QS. Declination is therefore unknown, but the inclination-only results obtained provide useful information. Seixal is situated on the left bank of the Tagus
Correspondence: Michael Edwin Evans, Physics Department, Institute for Geophysical Research, University of Alberta, T6G 2G7, Edmonton, Canada.

Tel.: +1.7804327864.

E-mail: tedevans.evans403@gmail.com

Key words: Archaeomagnetism; Pottery kilns; Portugal.

Contributions: Both authors participated in the field work and in the writing of the manuscript. All the experimental work was carried out by MEE.

Conflict of interest: the authors declare no potential conflict of interest.

Acknowledgments: the authors would like to thank Guilherme Cardoso, Joaquim Carvalho, and Jorge Raposo, archaeologists. This work would have been impossible without their advice and generous assistance. The authors also thank Gerry Hoye for helping with Matlab

Funding: financial support provided by the Natural Sciences and Engineering Research Council of Canada and the Geophysical Centre of the University of Évora.

Received for publication: 3 April 2017.

Revision received: 30 August 2017.

Accepted for publication: 31 August 2017.

This work is licensed under a Creative Commons Attribution NonCommercial 4.0 License (CC BY-NC 4.0).

(C) Copyright M.E. Evans, A. Correia, 2018 Licensee PAGEPress, Italy

Open Journal of Archaeometry 2018; 4:7171 doi:10.4081/arc.2018.7171

estuary, and the pottery finds indicate that amphorae for the fishing industry were produced in these kilns. But a wide variety of other pottery items were made here, including kitchenware, tableware, and oil lamps.

Samples from well-fired parts of the kilns were collected by bonding $2 \times 2 \mathrm{~cm}$ plastic squares onto each structure at convenient points to provide a planar surface to be orientated by solar bearings and bubbleinclinometer. Once removed from the surface, the samples were carefully wrapped in kitchen paper for transport to the laboratory. If they appeared to be fragile, a coating of varnish was first applied. Typically, samples have a mass of 10 to 20 grams and are irregular in shape. In the laboratory each sample was set in plaster in a $5 \mathrm{~cm}$-diameter cylindrical mould. Conventional spinner and cryogenic magnetometers cannot accept such large samples, so we used a Molspin 
large sample spinner magnetometer (Figure 4). A blank plaster sample gave no detectable signal. Magnetic stability was checked by standard progressive alternating-field (AF) demagnetization. Isothermal remanent magnetizations (IRMs) were given by means of a 2 G660 Pulse Magnetizer.

\section{Results and Discussion}

Test samples from each kiln responded to AF demagnetization in a straightforward manner, decaying monotonically to the origin with little evidence of significant secondary magnetic overprints (Figure 5A). Median destructive fields (MDFs) lie in the range 15-40 $\mathrm{mT}$, with significant remanence (10-20\%) remaining at the highest demagnetization steps (Figure 5B). The lower coercivities can be attributed to magnetite and/or titanomagnetite, but the higher coercivities imply a contribution from hematite (Dankers, 1981). This was confirmed by IRM experiments. We use the $\mathrm{d}$ factor defined by Butler (1982) as d=[(IRM ${ }_{600} \mathrm{mT}$ $\left.\left.\mathrm{IRM}_{300} \mathrm{mT}\right) / \mathrm{IRM}_{300} \mathrm{mT}\right]$, low values of which imply dominance of magnetite/titanomagnetite. Samples PN08, QR03 and CD07 yield values of 0.02, 0.04, and 0.14 , respectively. The coercivity spectra, as reflected by MDF and d values, are

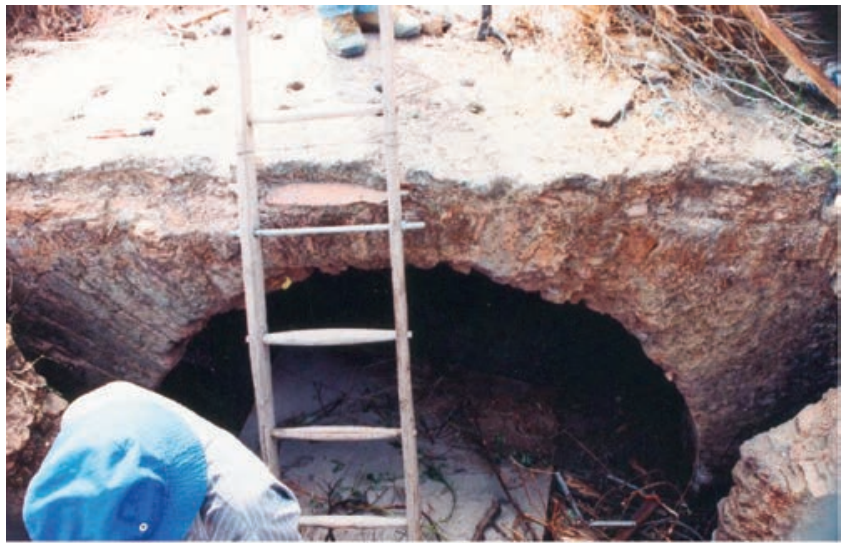

Figure 1. Kiln CD near the town of Castelo de Vide. The perforated floor of the firing chamber, and the underlying combustion chamber, are clearly visible. The basal part of the next arch supporting the (now removed) continuation of the firing chamber floor is visible in the lower right.

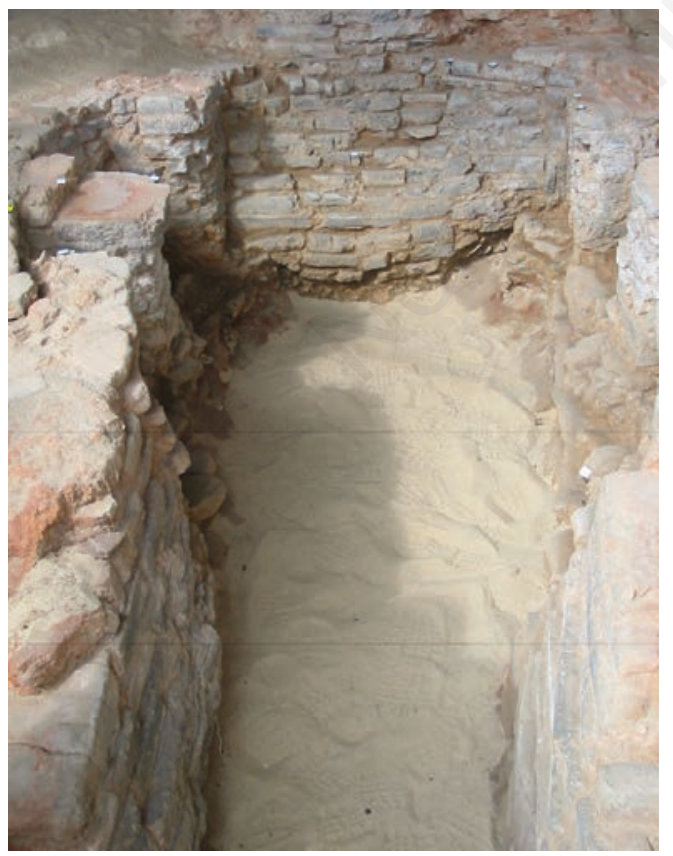

Figure 3. Kiln QR at Seixal. Only the combustion chamber and its access corridor are preserved. The positions of some of the samples are visible as small white plastic squares. Kiln QS is essentially identical to $Q R$ and is situated $4 \mathrm{~m}$ to the North.

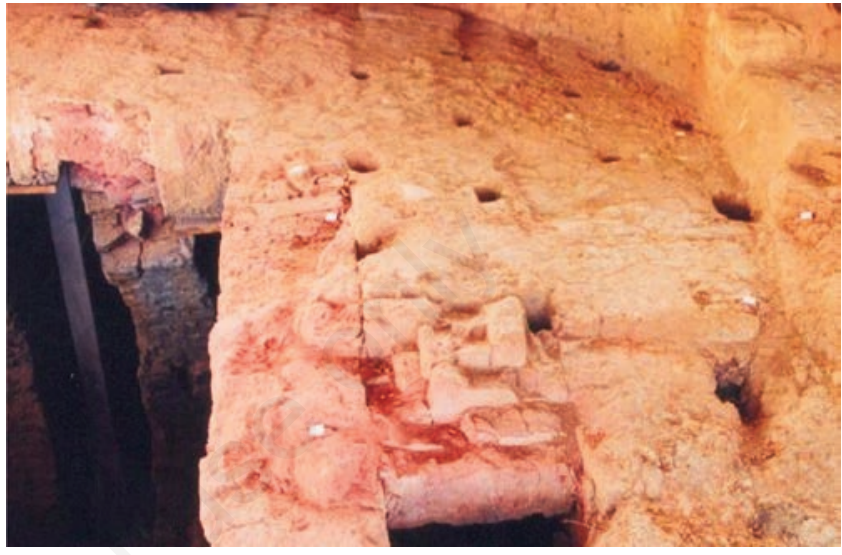

Figure 2. Kiln PN at Peniche. The perforated floor of the firing chamber is clearly visible. Part of this floor has collapsed, allowing the underlying combustion chamber to be seen at the lower left. The positions of some of the samples are visible as small white plastic squares.

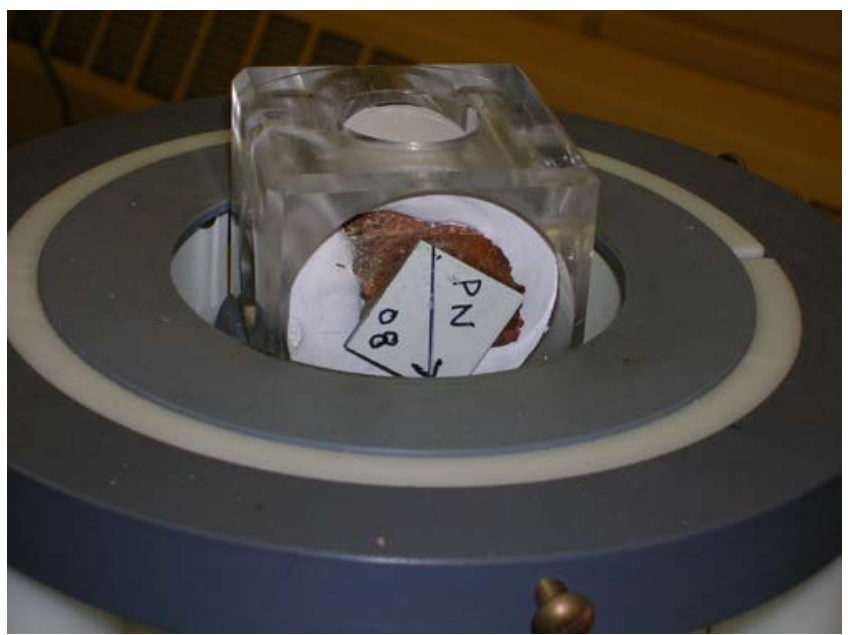

Figure 4. A typical sample being lowered into the cylindrical magnetic shield of the Molspin spinner magnetometer. The plastic square measures $2 \times 2 \mathrm{~cm}$. 
Table 1. Summary of archaeomagnetic results for each kiln.

\begin{tabular}{lccccccccc} 
Site & $\mathrm{N}$ & $\mathrm{k}$ & $\mathrm{a}_{95}$ & $\mathrm{a}_{63}$ & $\mathrm{Ds}$ & $\mathrm{Is}$ & $\mathrm{Dm}$ & $\mathrm{Im}$ & $\mathrm{d}$ \\
CD $(39.48,7.40)$ & 12 & 356 & 2.1 & 1.2 & -1.4 & 54.4 & -1.0 & 55.3 & 332 \\
PN $(39.38,9.36)$ & 7 & 439 & 2.5 & 1.5 & 0.2 & 54.0 & 0.8 & 55.1 & 496 \\
\hline QR $(38.63,9.10)$ & 8 & 316 & 2.8 & 1.6 & -3.9 & 51.7 & -3.2 & 53.3 & 503 \\
QS $(38.63,9.10)$ & 7 & 405 & 2.6 & 1.5 & - & 50.9 & - & 52.5 & 503 \\
\hline
\end{tabular}

Site (latitude North, longitude West); $N$, number of samples; k, Fisher's s precision parameter; $\alpha_{95}, \alpha_{63}$, semi-angle of cone of confidence at $95 \%$ and $63 \%$ probability levels (the latter corresponds to the angular standard error); Ds, site mean declination; Is, site mean inclination; Dm, Im, after relocation to Madrid using the Virtual Geomagnetic Pole method of Noël and Batt (1990) except QS, for which the inclination was adjusted assuming a geocentric axial dipole; $\mathrm{d}$, great circle distance from Madrid (km). McFadden and Reid (1982) method was used to analyse the inclination-only data from kiln QS.
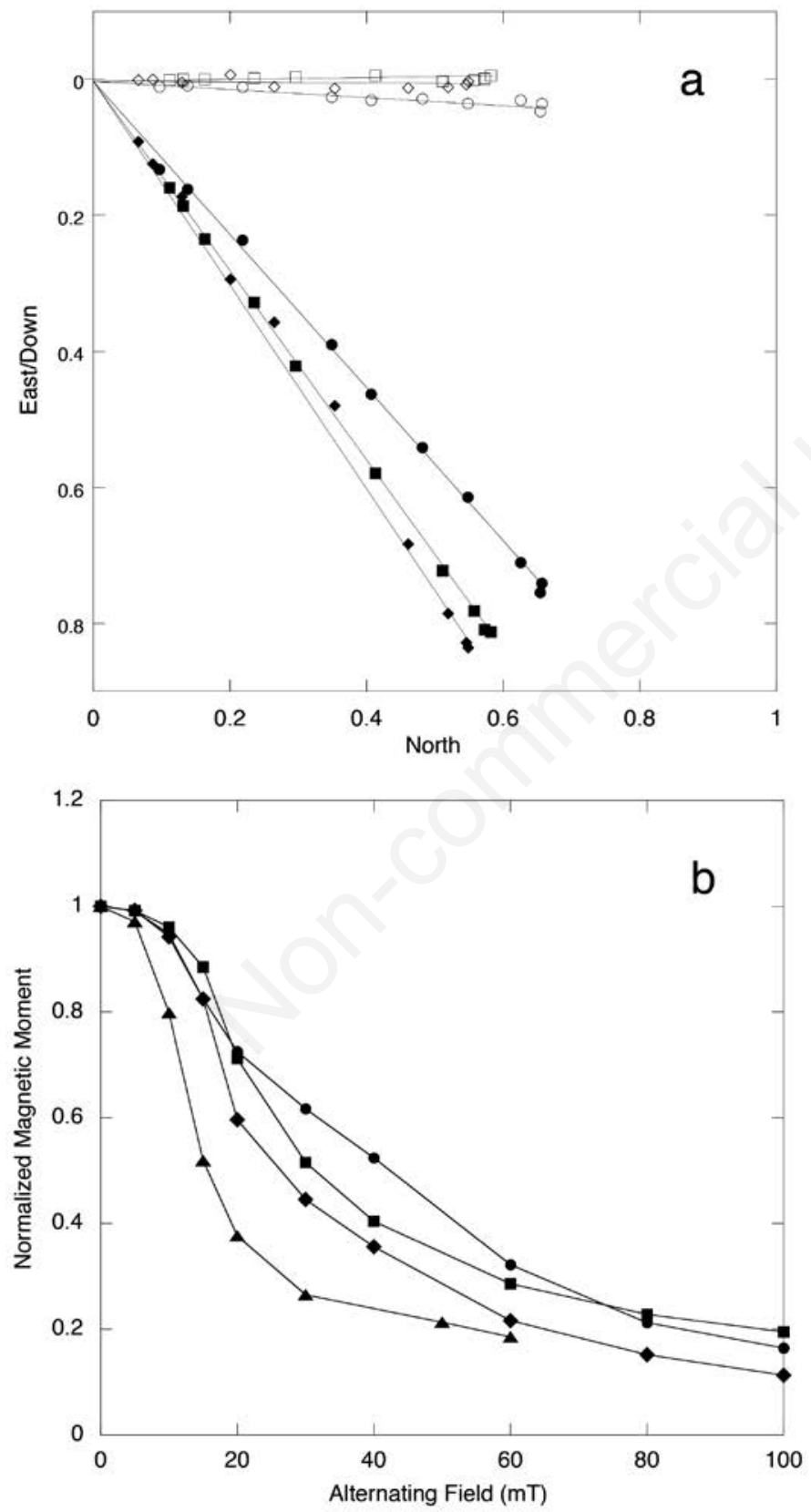

Figure 5. A) Normalized vector end-point plots for samples from kilns CD, PN, and QR. Closed (open) symbols are on the vertical (horizontal) plane; B) Corresponding normalized demagnetization curves. Squares $=$ CD07, diamonds $=$ PN08, circles $=Q R 03$, triangles=QS09 typical of baked archaeological materials. In a survey of 92 samples from 37 sites in Greece, Italy, North Africa, and China (including bricks, kiln wall fragments, and pottery sherds), Evans and Jiang (1996) found an MDF distribution with values of $17 \mathrm{mT}, 19 \mathrm{mT}$, and $29 \mathrm{mT}$ for the first quartile, median, and third quartile, respectively. Corresponding values for the distribution of $\mathrm{d}$ are 0.02, 0.04, and 0.07.

Behaviour during AF demagnetization (vector decay plots and MDFs) parallels experience at Italian and Greek sites (Evans and Hoye, 2005; Evans, 2006). Consequently, the bulk of the samples were treated at 5, 10, and $15 \mathrm{mT}$. The site mean directions are very stable as demagnetization proceeds, movements being no more than 1 or 2 degrees. We take the data after $10 \mathrm{mT}$ demagnetization as best representing the characteristic remanent magnetization, but the choice is not critical. We also found that Principal Component Analysis (PCA) (Kirschvink, 1980) yielded very similar results to our procedure. For example, by our method sample QR03 gives declination $(\mathrm{D})=2.8^{\circ}$ and inclination $(\mathrm{I})=48.6^{\circ}$, whereas PCA on the 10-100 $\mathrm{mT}$ demagnetization steps yields $\mathrm{D}=2.9^{\circ}, \mathrm{I}=47.9^{\circ}$ (maximum angular deviation $=1.5^{\circ}$ ). The difference between the two methods is negligible. The site results obtained by our procedure are summarized in Table 1.

For comparison with the regional secular variation (SV) reference curve proposed by Gómez-Paccard et al. (2006b) these new archaeodirections are relocated to Madrid via the virtual geomagnetic pole method. The sites all lie within the $600 \mathrm{~km}$ inner cir-

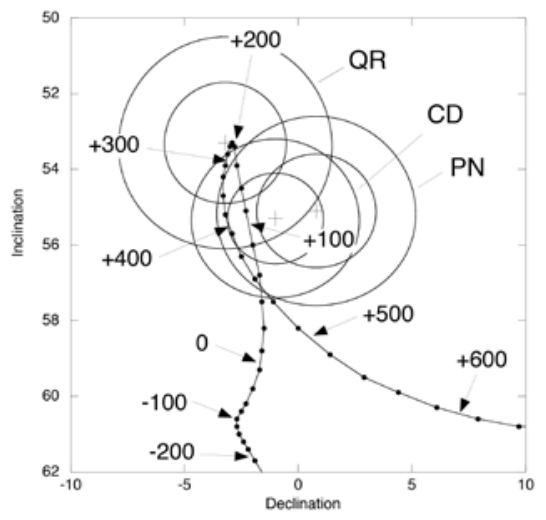

Figure 6. Archaeomagnetic directions for kilns $C D, P N$, and $Q R$ transposed to Madrid via the Virtual Geomagnetic Pole method. The larger (smaller) circles indicate the $\alpha_{95}\left(\alpha_{63}=\right.$ angular standard error $)$ confidence cones for each kiln. The relevant part of the secular variation curve of Gómez-Paccard et al. (2006b) is shown. Negative (positive) dates are BCE. Equirectangular projection. 
A
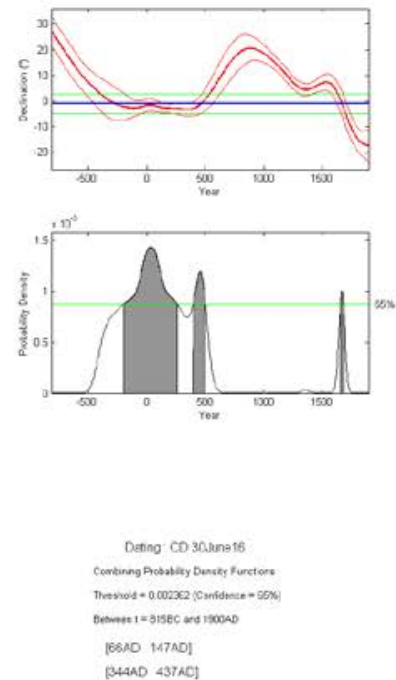

B
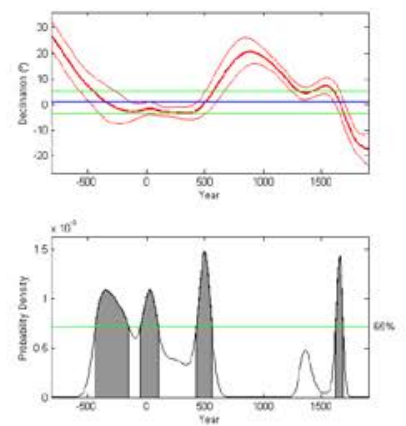

Deding Ptisosine to

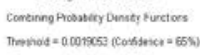

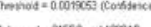
[59:0 154a0] [3A4AD SEDAC]

C
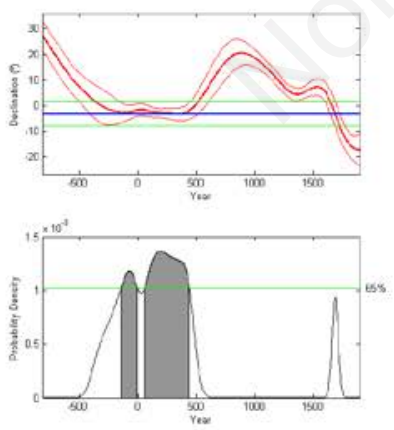

Deting OR SOUun to

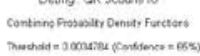

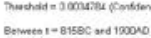
[LA7AO 309AC]
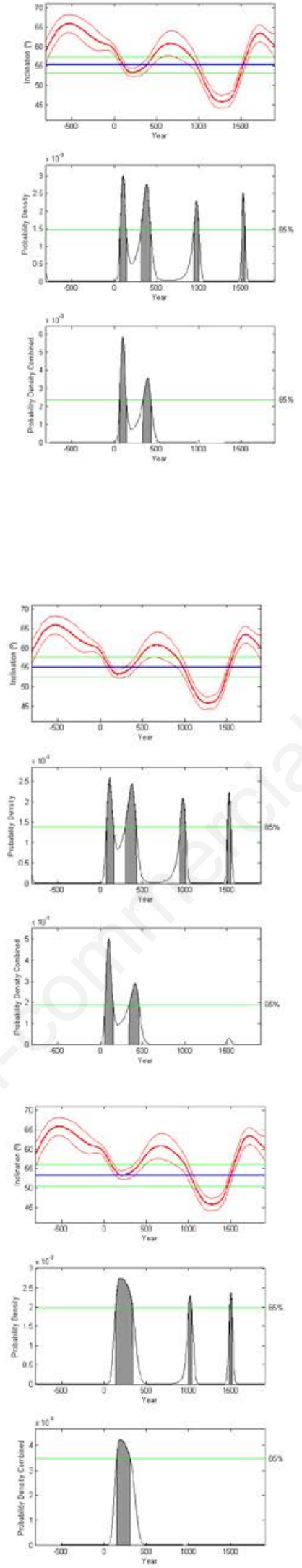

Figure 7. Probability-age density functions obtained from the Matlab tool of PávonCarrasco et al. (2011) for kilns A) CD, (B) PN, and C) QR.

cle of Gómez-Paccard and her co-authors. The inclination-only result for kiln QS was adjusted to Madrid on the assumption of a geocentric axial dipole. The mean archaeodirections for kilns CD, PN, and QR are shown on a rectangular plot in Figure 6. For relatively small areas, this type of plot offers a virtually distortion-free alternative to the traditional equal-area projection. No result is plotted for kiln QS because there is no associated declination value, but the inclination value $\left(52.5^{\circ}\right)$ agrees well with the other kiln at Seixal (QR). Indeed, all the kiln archaeodirections lie close to one another, with considerable mutual overlap of the associated confidence circles. The relevant part of the reference curve (from table n. 2 of Gómez-Paccard et al., 2006b) is also shown. The Bayesian approach used to construct the reference curve leads to irregular time intervals. For convenience, we indicate the turn of each century, with negative (positive) values being BCE (CE). The new Portuguese results support the published reference curve and expand its geographical coverage. However, the potential of archaeomagnetic dating during the Roman period is limited by the very nature of the secular variation itself. PávonCarrasco et al. (2011) point out that this restricted geomagnetic change severely limits the ability of modern computational schemes (including their own) to provide high-resolution dates for Roman sites. This is not a new problem, it merely shows that what was true of, say, the earlier French data (Thellier, 1981) is also true for the modern Iberian data. Nevertheless, a common-sense approach - that the best estimate for the age of an archaeological feature corresponds to the point on the reference curve that is closest to its mean direction - suggests that kilns CD and PN date to about $100 \mathrm{CE}$, whereas kiln QR dates to about 200 CE. The mathematical procedure of PávonCarrasco et al. (2011) confirms these visual assessments and provides quantitative estimates of their associated uncertainty. The probability peaks and 65\% age brackets are virtually identical for $\mathrm{CD}$ and $\mathrm{PN}$. For $\mathrm{CD}$, the peak occurs at $103 \mathrm{CE}$, with brackets of 66-147 CE (Figure 7A). For PN, the corresponding values are $102 \mathrm{CE}$ and 59-154 CE (Figure 7B). The peak for QR occurs at 196 $\mathrm{CE}$, with a wider range (147-309 CE) due to the fact that the geomagnetic field was essentially stationary for the whole of the 3rd century (Figure 7C). The repetitive nature of the SV curve leads to the appearance of smaller peaks near $400 \mathrm{CE}$ for kilns $\mathrm{CD}$ and PN. While these later dates cannot be rejected as formal possibilities, their acceptance would lead to the awkward difficulty of why the earlier peaks - which are 
twice as high - should be ignored. More archaeological information could potentially settle the matter. Currently, the only relevant evidence available are the amphora stamps at Peniche. These favour the earlier date.

\section{Conclusions}

Archaeodirectional results are reported from four Roman kilns at three sites in central Portugal. All samples exhibit excellent demagnetization characteristics, and the kiln means are tightly constrained (95\% confidence limits $\leq 2.8^{\circ}$, angular standard errors $\leq 1.6^{\circ}$ ). These robust results support the published regional secular variation reference curve, and extend its geographic coverage. They imply that the kilns at Castelo de Vide and Peniche were both in operation during the late $1^{\text {st/early }} 2^{\text {nd }}$ centuries CE, whereas those at Seixal date between the late $2^{\text {nd }}$ and earliest $4^{\text {th }}$ centuries $\mathrm{CE}$.

\section{References}

Abrahamsen N, 1996. An archaeomagnetic master curve for Denmark 0-2000 AD and the possible dating accuracy. Proceedings of the Sixth Nordic Conference on the Application of Scientific Methods in Archaeology 1993. Arkæologiske Rapporter, 1, EsbjergMuseum. pp 261-271.

Aitken MJ, Weaver GH, 1962. Magnetic dating: some archaeomagnetic measurements in Britain. Archaeometry 5:4-25.

Bucur I, 1994. The direction of the terrestrial magnetic field in France during the last 21 centuries. Phys Earth Planetary Interiors 87:95-109.

Butler RF, 1982. Magnetic mineralogy of Continental Deposits, San Juan Basin, New Mexico and Clark's Formation, Wyoming. J Geophys Res 87:7843-52.

Catanzariti G, McIntosh G, Soares AMM, Díaz-Martínez E, Kresten P, Osete ML, 2008. Archaeomagnetic dating of a vitrified wall at the Late Bronze Age settlement of Misericordia (Serpa, Portugal). J Archaeol Sci 35:1399-407.

Cardoso G, Gonçalves JL, Rodrigues S, 1998. Forno Romano de Cerâmica
Descoberto em Peniche. Al-Madan, Series II; 7:178.

Cook RM, Belshé JC, 1958. Archaeomagnetism: a preliminary report from Britain. Antiquity 32:16778.

Dankers P, 1981. Relationship between median destructive field and remanent coercive forces for dispersed natural magnetite, titanmagnetite and hematite. Geophys J R Astr Soc 64:447-61.

De Marco E, Tema E, Lanos P, Kondopoulou D, 2014. An updated catalogue of Greek archaeomagnetic data for the last 4500 years and a directional secular varation curve. Stud Geophys Geod 58:121-47.

Evans ME, 2006. Archaeomagnetic investigations in Greece and their bearing on geomagnetic secular variation. Phys Earth Planet Int 159:90-5.

Evans ME, Hoye GS, 2005. Archaeomagnetic results from southern Italy and their bearing on geomagnetic secular variation. Phys Earth Planet Int 151:155-162.

Evans ME, Jiang L, 1996. Magnetomineralogy of archeomagnetic materials. J Geomag Geoelec 48:153140.

Folgheraiter G, 1899. Sur les variations séculaires de l'inclinaison magnétique dans l'antiquité. J Phys 8:660-7.

Gómez-Paccard M, Catanzariti G, RuizMartínez VC, McIntosh G, Núñez JI, Osete ML, Chauvin A, Lanos P, Tarling DH, Bernal-Casasola D, Thiriot J, Archaeological Working Group, 2006a. A catalogue of Spanish archaeomagnetic data. Geophys J Int 166:1125-43.

Gómez-Paccard M, Lanos Ph, Chauvin A, McInstosh G, Osete ML, Catanzariti G, Ruiz-Martínez VC, Núñez JI, 2006b. First archaeomagnetic secular variation curve for the Iberian Peninsula. Comparison with other data from Western Europe and with global geomagnetic field models. Geochem Geophys Geosyst 7:Q12001.

Hus J, Geeraerts R, 1998. The direction of the geomagnetic field in Belgium since Roman times and reliability of archaeomagnetic dating. Phys Chem Earth 23:997-1007.

Kirschvink JL, 1980. The least-squares line and plane and the analysis of palaeomagnetic data. Geophys J R Astr Soc
62:699-718.

Kovacheva M, Kostatinova-Avramova M, Jordanova N, Lanos Ph, Boyadzhiev Y, 2014. Extended and revised archaeomagnetic database and secular variation curves from Bulgaria for the last eight millennnia. Phys Earth Planetary Interiors 236:79-94.

Márton P, 2003. Recent achievements in archaeomagnetism in Hungary. Geophys J Int 153:675-90.

McFadden PL, Reid AB, 1982. Analysis of palaeomagnetic inclination data. Geophys J R Astr Soc 69:307-19.

Noël M, Batt CM, 1990. A method for correcting geographically separated remanence directions for the purpose of archaeomagnetic dating. Geophys J Int 102:753-6.

Pávon-Carrasco FC, Rodríguez-González J, Osete ML, Torta JM, 2011. A Matlab tool for archaeomagnetic dating. J Archaeol Sci 38:408-19.

Schnepp E, Lanos P, 2005. Archaeo-magnetic secular variation in Germany during the past 2500 years. Geophys J Int163:479-90.

Schnepp E, Lanos P, 2006. A preliminary secular variation reference curve for archaeomagnetic dating in Austria. Geophys J Int 166:91-6.

Spassov S, Hus J, Geeraerts R, Heller F, 2008. Archaeomagnetic dating of a High Middle Age likely iron working site in Corroy-le-Grand (Belgium). Phys Chem Earth 33:544-56.

Tema E, Hedley I, Lanos P, 2006. Archaeomagnetism in Italy: a compilation of data including new results and a preliminary Italian secular variation curve. Geophys J Int 167: 1160-71.

Thellier É, 1936. Aimantation des briques et inclinasion du champ magnétique terrestre. Ann Institut Phis Globe, Université de Paris, 14:65-70.

Thellier É, 1981. Sur la direction du champ magnétique terrestre en France durant les deux derniers millénaires. Phys Earth Planet Inter 24:89-132.

Zananiri I, Batt CM, Lanos P, Tarling DH, Linford P, 2007. Archaeomagnetic secular variationin the UK during the past 4000 years and its application to archaeomagnetic dating. Phys Earth Planet Int 160:97-107. 